\title{
28. NONVOLATILE ORGANIC MATTER AT SITES 565-570, DEEP SEA DRILLING PROJECT LEG 84¹
}

\author{
Mahlon C. Kennicutt II, James M. Brooks, Thomas J. McDonald, and Ronald C. Pflaum, \\ Department of Oceanography, Texas A\&M University ${ }^{2}$
}

\begin{abstract}
Organic-carbon content and carbon isotopic compositions within the Pleistocene and Pliocene-Oligocene sections at Sites 565-570 in the Middle American Trench area were internally consistent. For the Pleistocene section, a decrease in organic-carbon content toward present-day land and a relatively constant carbon isotopic composition $\left(\delta^{13} \mathrm{C}=-20.1\right.$ to $-21.6 \%$ ) was observed. For the Pliocene-Oligocene section, there is a general increase in organic-carbon content in the direction of present-day land. A general relationship between organic-carbon content and carbon isotopic ratios was observed where high organic-carbon levels were associated with heavier (more positive) carbon isotopic ratios and where low organic-carbon concentrations were associated with lighter (more negative) carbon isotope values. Hexane-extractable organic matter $(\mathrm{EOM})$ was generally less than $500 \mathrm{ppm}$ at all sites and showed a random distribution. Fluorescence spectral patterns confirmed the presence of a few in situ aromatic compounds and a low level background of migrated petrogenic hydrocarbons. High perylene concentrations were associated with organic-carbon isotopic compositions typical of marine organic matter.
\end{abstract}

\section{INTRODUCTION}

The distribution of organic matter in marine sediments is controlled by a number of factors including the amount and composition of the source material (biogenic or terrigenous), depositional environment (reduction-oxidation conditions), depth of burial (age and thermal history), geologic reworking (bioturbation, slumping, mass movement), and upward migration of liquids and gases from deeper accumulations resulting from the thermal alteration of organic matter. All these factors potentially influence the bulk organic-carbon content, isotopic composition, and individual molecular compositions of both the extractable and residual organic carbon in sediments. In a continuing effort to understand the factors controlling the distribution and early diagenesis of organic matter on continental margins and in the sedimentary column in general, selected samples from Site 565-570 were analyzed for organic-carbon content, carbon isotopic composition, and extractable organicmatter content using gravimetry, gas chromatography, isotope ratio mass spectrometry, and total scanning ultraviolet (UV) fluorescence. The chemical and isotopic compositions were measured in an attempt to detect early diagenetic transformations and to delineate the dynamics of the sources of organic matter.

\section{EXPERIMENTAL TECHNIQUES}

The methods employed in this study have been extensively described elsewhere (Kennicutt and Brooks, 1983; Kennicutt et al., in press) and will only be briefly presented here. Organic-carbon content was determined by direct combustion on a Craig-type system with manometric measurement of $\mathrm{CO}_{2}$. Carbon isotopic compositions were

\footnotetext{
${ }^{1}$ von Huene, R., Aubouin, J., et al., Init. Repts. DSDP, 84: Washington (U. S. Govt. Printing Office)

Address: Department of Oceanography, Texas A\&M University, College Station, TX
}

determined after the methods of Sackett et al. (1970). Samples were freeze-dried, ball-milled, acidified to remove inorganic carbon, and combusted to $\mathrm{CO}_{2}$ on a Craig-type combustion system. Isotopic analysis of $\mathrm{CO}_{2}$ was performed on a Nuclide RMS 60 Ratio Mass Spectrometer, and results were reported relative to the PDB standard. Precision of replicate samples was better than $\pm 0.2 \%$. Extractable organic-matter content was determined for freeze-dried sample aliquots by Soxhlet extraction for $12 \mathrm{hr}$. with spectrograde hexane (Burdick \& Jackson Laboratories, Inc.). A total extractable weight was determined using a Cahn Electrobalance. The extract was dissolved in $100 \mu \mathrm{l}$ of methylene chloride, and a $20-\mu \mathrm{l}$ aliquot was transferred to a preweighed filter pad. Extracts were further analyzed using a HewlettPackard 5880A Gas Chromatograph equipped with 50-m fused silica bonded phase capillary columns (50QC2/BPI; SGE, Ltd.). Temperature programmed gas chromatography $\left(80^{\circ} \mathrm{C}, 0 \mathrm{~min} . \rightarrow 300^{\circ} \mathrm{C}\right.$ at $6^{\circ} \mathrm{C} / \mathrm{min} . \rightarrow 300^{\circ} \mathrm{C}$ for $15 \mathrm{~min}$.) was performed using flame ionization detection. Total scanning UV fluorescence spectra of extracts were acquired using a microprocessor controlled Perkin-Elmer $650-40$ spectrofluorometer (Brooks, Barnard, et al., 1983; Brooks, Kennicutt, et al., 1983). Post-acquisition data manipulation was performed using an Amdahl computer and a standard statistical analysis package (SAS).

\section{RESULTS}

\section{Organic-Carbon Content and Carbon Isotopic Compositions}

\section{Site 565 (lower slope)}

Organic-carbon content in the Pleistocene section $(0-106 \mathrm{~m})$ averaged $1.10 \%$ and ranged from 0.60 to $1.64 \%$ (Fig. 1). Organic-carbon content in the Pliocene section $(106-286 \mathrm{~m})$ averaged $0.98 \%$ and varied from 0.37 to $1.35 \%$. These concentrations are very similar to those observed by Summerhayes (1980) and Summerhayes and Gilbert (1982a,b) for the continental margins extending along southern Mexico to northern California. The organic-carbon content variations may reflect changes in organic-matter input due to changing climatic, environmental, and circulatory patterns (i.e., upwelling). Vertical trends in the Pleistocene section have been disturbed as evidenced by slump folds (Site 565 report, this volume). Bioturbation and slump features document- 

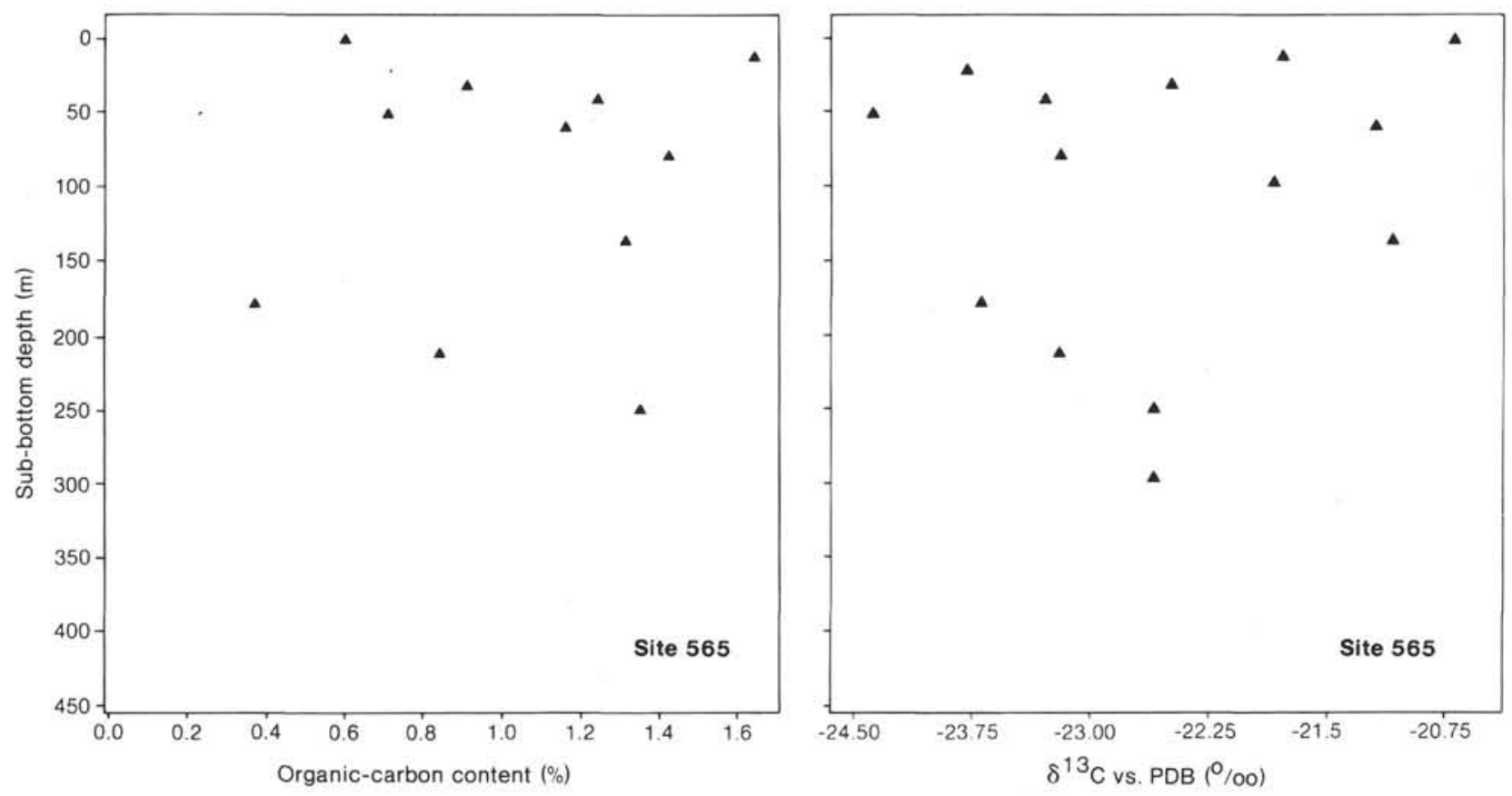

Figure 1. Distribution of organic-carbon content and carbon isotopic compositions with depth at Site 565.

ed at this site make the interpretation of the observed trends difficult.

The carbon isotopic composition of the organic matter also was distributed erratically at Site 565 (Fig. 1). Values for $\delta^{13} \mathrm{C}_{\text {org }}$ ranged between -20.7 and $-24.4 \%$. No regular trends with depth were observed. Most $\delta^{13} \mathrm{C}_{\text {org }}$ values were intermediate between those values typical of marine and terrestrial organic matter (Eckleman et al., 1962; Sackett and Thompson, 1963; Sackett, 1964; Calder, 1971; Gearing et al., 1977). This entire section is presumed never to have been in water depths shallower than $\sim 1500 \mathrm{~m}$ (Site 565 report, this volume). The $\delta^{13} \mathrm{C}_{\text {org }}$ distributions in the Pleistocene section may indicate the presence of terrestrial organic matter that probably was delivered to the site by downslope sediment movement. The alternating isotopic values may reflect sorting during several episodes of slump movement or turbidity flows or both (Rovang, 1981). The presence of terrestrial organic matter in deep-water sediments has been interpreted to be the result of along-slope transport of material brought to the base of the slope in fast-moving turbidity currents (Newman et al., 1973; Summerhayes and Gilbert, 1982a). The general $\delta^{13} C_{\text {org }}$ increase with depth in the Pliocene section is consistent with an increase in water depth to abyssal depths during this period, as suggested in the site reports.

\section{Site 566 (lower slope)}

The one sample analyzed at Site 566 at $1.4 \mathrm{~m}$ subbottom depth had an organic-carbon content that was relatively high $(3.97 \%)$. The organic-carbon isotopic composition was $-20.8 \%$.

\section{Site 567 (Cocos Plate)}

The organic-carbon content varied from 0.05 to $1.82 \%$, averaged $0.53 \%$, and generally decreased with depth at
Site 567 (Fig. 2). The majority of the section analyzed was Miocene in age (215-325 m) and had a relatively low organic-carbon content, as previously documented for the Cocos Plate (Summerhayes and Gilbert, 1982a). The basement serpentinite layer $(325-359 \mathrm{~m})$ was very low in organic-carbon content, averaging $0.06 \%$.

Carbon-isotopic compositions confirm the observations of Harrison et al. (1981) from Legs 66 and 67. At Site 494 they observed that below $200 \mathrm{~m}$ sub-bottom depth, few samples exceeded $1.0 \%$ organic carbon and that underlying the Quaternary section, Pliocene and Miocene sediments contained organic matter with an isotopic composition typical of terrestrial organic matter. At Site 567 the carbon isotopic distribution in the Miocene section reveals a regular decrease in $\delta^{13} \mathrm{C}_{\text {org }}$ with depth. The trend is consistent throughout the analyzed section and occurs even across the suspected Pliocene/Miocene unconformity at $\sim 215 \mathrm{~m}$. The serpentinite layer had the most negative $\delta^{13} \mathrm{C}_{\mathrm{org}}$ values encountered on Leg 84 , averaging $-27.1 \%$.

\section{Site 568 (middle to upper slope)}

Organic-carbon content generally decreased with depth, averaging $2.20 \%$ (range $0.52-4.18 \%$ ) for the Pleistocene section $(0-182 \mathrm{~m}$ ) and $1.10 \%$ (range $0.50-1.7 \%$ ) for the deep Pliocene-Oligocene section (Fig. 3). There is evidence of bioturbation in this latter section (Site 568 report, this volume).

Carbon isotopic analysis of the organic matter shows a distinct break between what has previously been interpreted as predominantly marine organic matter in the Pleistocene section $\left(\delta^{13} \mathrm{C}_{\text {org }}\right.$ range -20.5 to $-22.1 \%$ ) and the lighter (more negative) values observed in the Pliocene section. Only one section in the Pleistocene sediments had a $\delta^{13} \mathrm{C}_{\text {org }}$ value lighter than $-22.0 \%$. This value was near the Pleistocene/Pliocene boundary and 

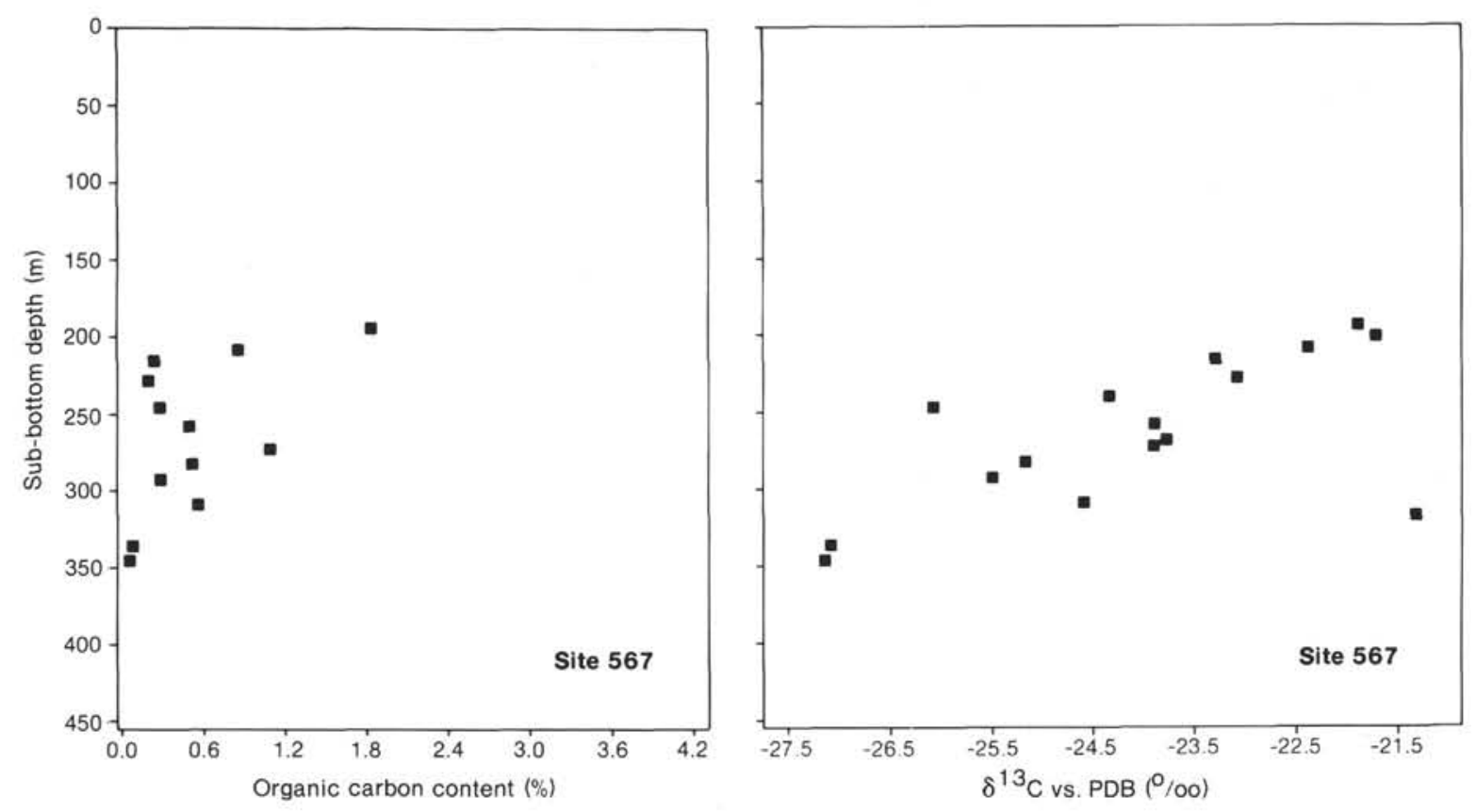

Figure 2. Distribution of organic-carbon content and carbon isotopic compositions with depth at Site 567.
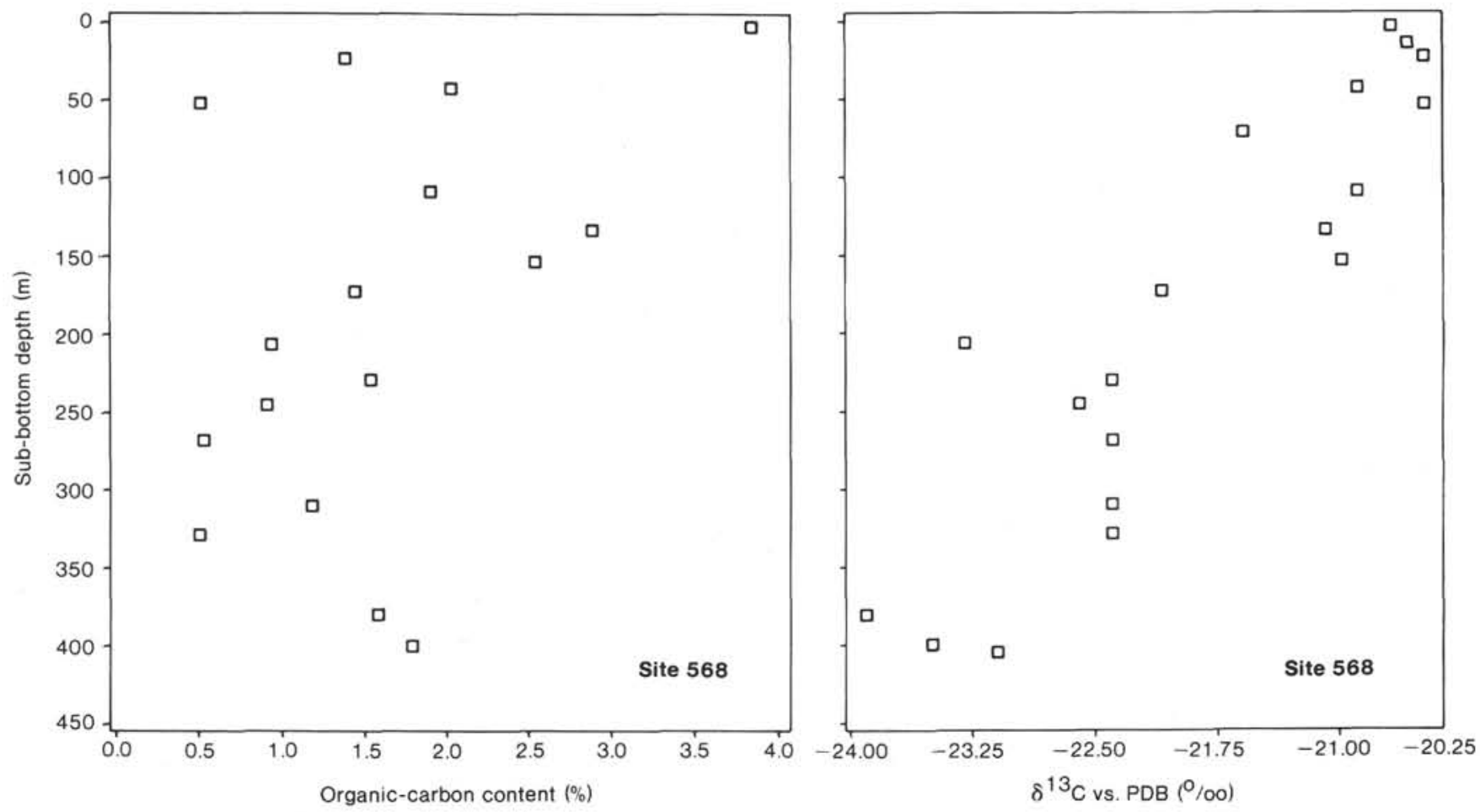

Figure 3. Distribution of organic-carbon content and carbon isotopic compositions with depth at Site 568.

could have resulted from sediment reworking. The Pliocene-Oligocene section had $\delta^{13} C_{\text {org }}$ values less than $-22.0 \%$, and the deepest sections had values less than $-23.0 \%$. This range of $\delta^{13} \mathrm{C}_{\text {org }}$ values can represent a mixture of marine and terrestrial organic-matter inputs but could also result from the early diagenesis of organic matter. As at Site 567, a general decrease of $\delta^{13} C_{\text {org }}$ with depth is observed. Excursions from this trend are possibly caused by slumping, mass movement, and bioturbation.

\section{Site 569 (midslope)}

As at other sites, although more regular, a general decrease in organic-matter content with depth is observed (Fig. 4). Organic-carbon content averaged $2.10 \%$ (range $1.60-2.63 \%)$ in the Pleistocene section $(0-50 \mathrm{~m})$ and 

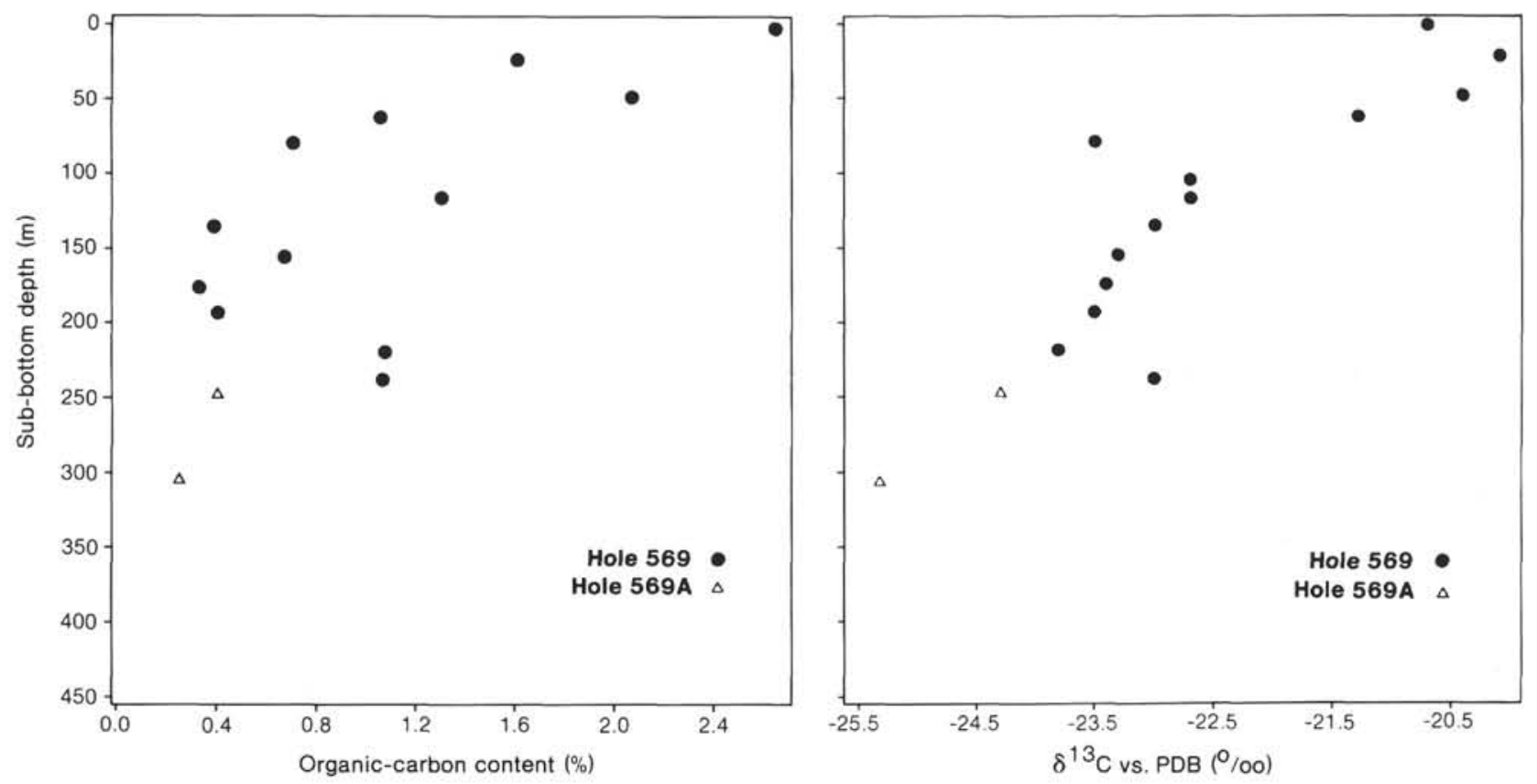

Figure 4. Distribution of organic-carbon content and carbon isotopic compositions with depth at Site 569.

$0.69 \%$ (range $0.25-1.30 \%$ ) in the Pliocene-Oligocene section $(50-313 \mathrm{~m})$.

Carbon-isotopic compositions of organic matter paralleled that observed at Site 568. Pleistocene $\delta^{13} \mathrm{C}_{\text {org }}$ values were similar to those typical of marine organic matter $(-20.1$ to $-20.7 \%$ ). A general gradation toward typical terrestrial $\delta^{13} \mathrm{C}_{\text {org }}$ values is observed through the Pliocene-Oligocene section $(-21.3$ to $-25.1 \%$ ). These changes in carbon isotopic composition could also be explained by fluctuations in water temperature in the euphotic zone.

\section{Site 570 (upper slope)}

Organic-carbon content generally decreases with depth at Site 570 but not in as regular a manner as at Site 569 (Fig. 5). Site 570 is the most landward location (with respect to present-day shoreline) on Leg 84 and has a thick Pleistocene section (0-211 m). Organic-carbon content in the Pleistocene section averaged $1.61 \%$ (range 0.98 $2.33 \%$ ). Organic-carbon content decreased with depth in the Pleistocene section, although not regularly. The two samples that were analyzed from the Pliocene-Oligocene section were relatively high in organic-carbon content $(1.34$ and $3.20 \%)$. One sample from the lower Eocene contained $1.33 \%$ organic carbon. The carbon isotopic composition of the organic matter at Site 570 was constant with depth and varied by only $1.5 \%$. All $\delta^{13} \mathrm{C}_{\text {org }}$ values were heavier than $-22.0 \%$.

\section{Extractable Organic Matter (EOM)}

Hexane-extractable organic matter was analyzed using gravimetry, gas chromatography, and total scanning fluorescence. All sites were characterized by low amounts of EOM (generally $<500 \mathrm{ppm}$ ) and by random distributions with depth. The distribution of the $n$-alkanes (as exemplified by the carbon preference index) is not pre- sented because of the sporadic occurrence of significant amounts of these compounds. Typical gas chromatograms are presented in Figure 6 . The unresolved complex mixture observed may be the result of small amounts of migrated petrogenic hydrocarbons.

\section{Site 565}

The EOM varied from 14 to $520 \mathrm{ppm}$ and showed no regular trend with depth (Fig. 7); it was generally less than $200 \mathrm{ppm}$. Pristane/phytane ratios varied from 0.81 to 3.19. Again, no significant trend with depth was observed.

\section{Site 566}

In the single sample analyzed at $1.4 \mathrm{~m}$ sub-bottom depth, the pristane concentration was high relative to phytane, with the ratio being 3.97. Pristane is presumed to be of phytoplankton origin, and thus this ratio is consistent with the organic-carbon isotopic ratio of $-20.8 \%$, indicative of a marine source.

\section{Site 567}

The EOM varied from 36 to $225 \mathrm{ppm}$ at this site (Fig. 8 ). A very irregular decrease with depth was observed. Pristane/phytane ratios were also randomly distributed and varied from 0.69 to 1.91 .

\section{Site 568}

The EOM and pristane/phytane ratios were similar to those reported for Site 567 (Fig. 9). The EOM ranged from 17 to $461 \mathrm{ppm}$ and the pristane/phytane ratios ranged from 0.4 to 2.2 .

\section{Site 569}

The EOM generally decreased with depth although several samples are outside of this trend (ranging from 

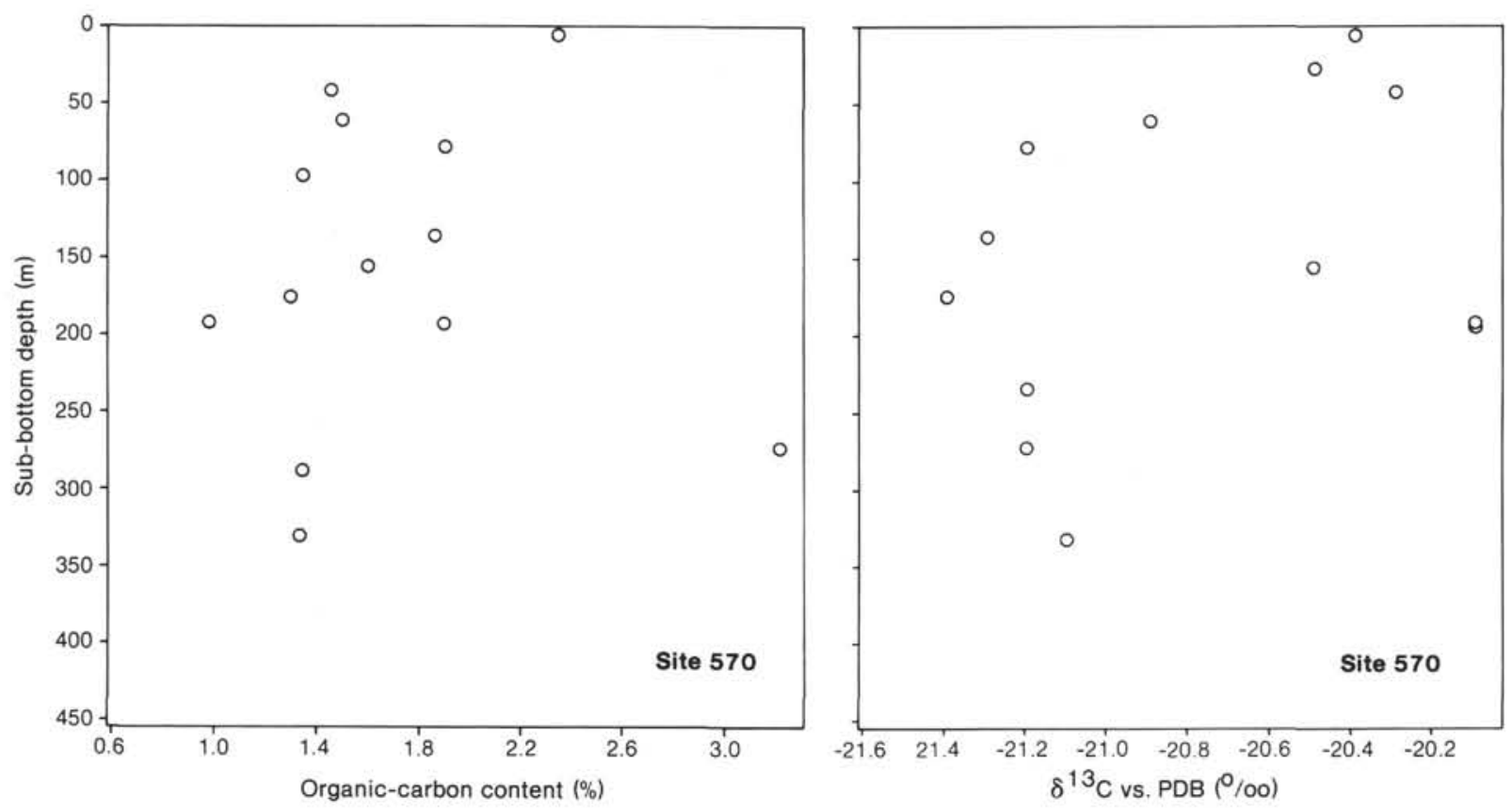

Figure 5. Distribution of organic-carbon content and carbon isotopic compositions with depth at Site 570.

12 to $254 \mathrm{ppm}$ ). Pristane/phytane ratios generally increased with depth and ranged from 0.62 to 1.68 (Fig. 10).

\section{Site 570}

Again, the EOM was low in concentration and nearly randomly distributed (ranging from 16 to $252 \mathrm{ppm}$ ) (Fig. 11). Pristane/phytane ratios generally decreased with depth and ranged from 0.89 to 2.84 .

\section{Fluorescence}

Total scanning UV fluorescence patterns were obtained for all extracts. Figure 12 shows typical spectra from Site 568. In general the patterns are typical of recent marine sediments (Brooks, Barnard, et al., 1983; Brooks, Kennicutt, et al., 1983; Kennicutt and Brooks, 1983; and Kennicutt et al., in press), and no trend with depth was observed. As a sensitive fingerprint of aromatic compounds, the fluorescence results show that very little diagenetic production of aromatic compounds from the bulk organic matter, other than perylene, has occurred at the depths analyzed. Also, only low-level migrated liquid hydrocarbons are present. Perylene was consistently detected throughout the length of the cores. A second, lower wavelength, fluorescence peak was also usually present. The exact molecular species responsible for this low wavelength peak are not presently known, but it has been extensively detected in recent sediments from continental margins and may be the result of nonindigenous hydrocarbons.

\section{DISCUSSION}

The carbon isotopic composition of bulk organic carbon and the molecular composition of the EOM can be used to discern source relationships and early diagenetic transformations in a sedimentary column. Typically, the distribution of terrestrial and marine organic matter in present-day depositional environments has been used to infer past oceanographic conditions as reflected in ancient sediments. Attempts to differentiate between marine and terrestrial organic matter have been based primarily on isotopic $\left(\delta^{13} C\right)$ and chemical ( $n$-alkanes, lignin, and elemental composition) differences (Eckleman et al., 1962; Sackett and Thompson, 1963; Sackett, 1964; Hunt, 1970; Calder, 1971; Gardner and Menzel, 1974; Hedges, 1975; Hedges and Parker, 1976; Gearing et al., 1977). It has been demonstrated that terrestrial plants are enriched in ${ }^{12} \mathrm{C}$ relative to marine plants (Wickman, 1952; Craig, 1953) and that the average composition of terrestrial and marine plants differs by $\sim 8 \%$ (Sackett, 1964). On the basis of this difference, it has been suggested that the relative input of terrestrial versus marine organic matter into sediments can be inferred. However, this interpretation is complicated by several factors including: (1) the overlap of the isotopic composition of marine and terrestrial plants; (2) the effects of water temperature on the isotopic fractionation of carbon in plankton; (3) the alteration of organic-matter isotopic composition during degradation and diagenesis; (4) migration of petrogenic hydrocarbons from deeper reservoirs to shallow sediments; (5) anomalous isotopic compositions that can be produced in localized (closed) environments; and (6) the incorporation of recycled organic matter into recent sediments.

Several studies of carbon isotopic compositions in recent sedimentary environments such as the Gulf of Mexico, Mississippi Delta, Niger Delta, and Beaufort Sea have suggested that in normal shelf sediments the following points are true: (1) Variations in the $\delta^{13} \mathrm{C}$ of organic matter primarily result from the relative amounts of terrestrial and marine organic matter, and in a depositional environment (such as a delta), gradients are observed extending seaward. (2) Terrestrial organic matter 

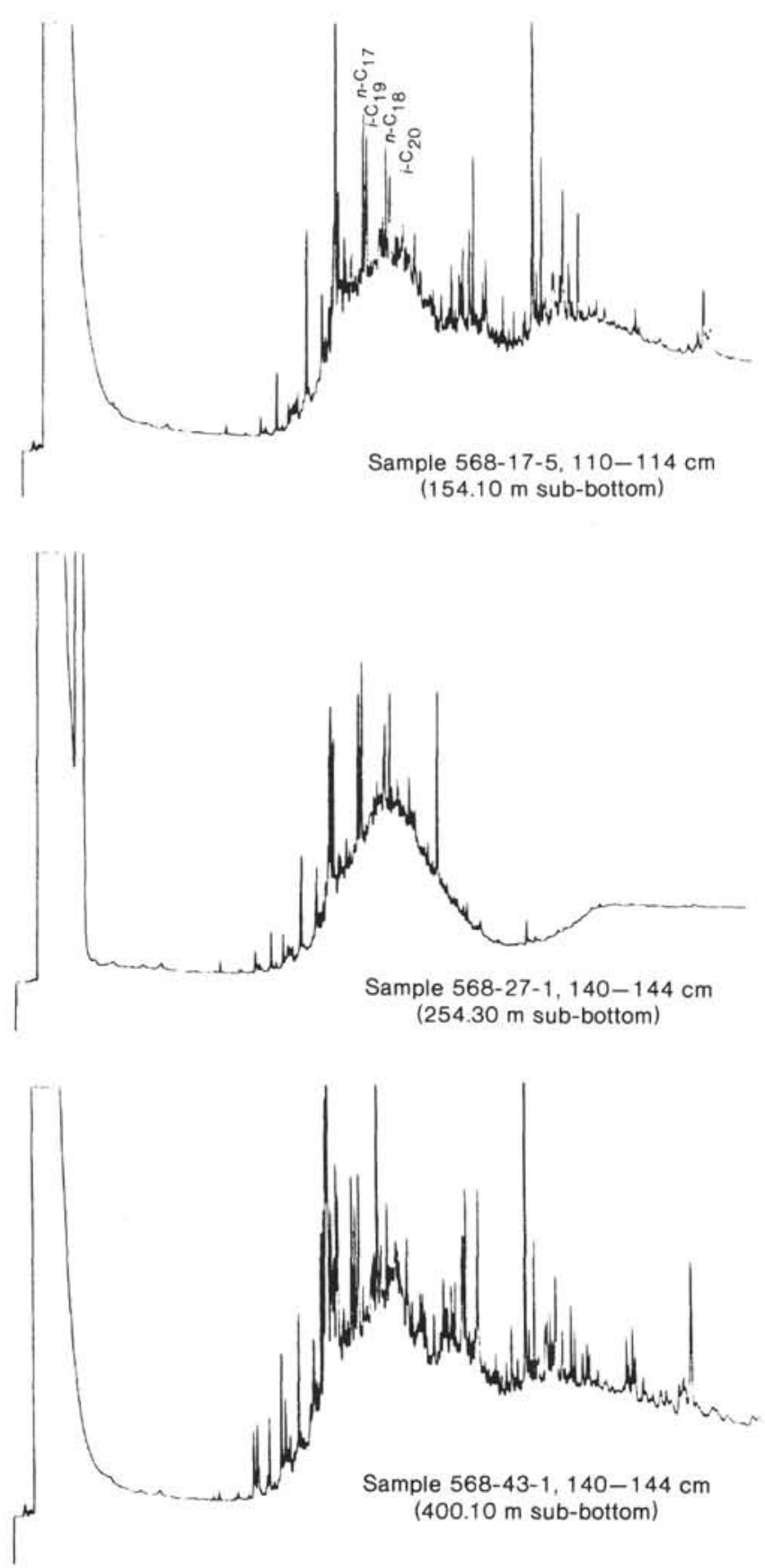

Figure 6. Representative gas chromatograms of hexane-extractable organic matter at Site 568 .

exerts a minor influence in establishing the $\delta^{13} \mathrm{C}_{\text {org }}$ values in continental margin sediments. (3) Even in areas of heavy runoff and sediment input (such as deltas), locally produced marine organic matter dilutes the contribution from land plants. (4) The dilution is rapid and approaches a logarithmic decrease with distance from shore. (5) A definite terrestrial input is seen only very close to land where a significant proportion of the total organic matter consists of the remains of woody plants. (6) The isotopic ratios observed in recent marine sediments are dependent on the $\delta^{13} \mathrm{C}$ values of primary pro- ducers that can be affected by nutrients and water temperature (Gearing et al., 1977; Sackett, 1964).

At Sites 565 through 570, decreasing organic-carbon content is accompanied by a decrease in carbon isotopic ratios (Fig. 13). On the basis of the previously mentioned studies, we propose that this trend may reflect the relatively low carbon levels associated with terrestrial input as well as the high water-column productivity (upwelling) that produces high levels of marine-dominated organic-carbon sedimentation. The preservation of the high levels of marine organic matter (up to 4\%) in the sediment may be the result of oxygen depletion (Summerhayes and Gilbert, 1982b; Lisitzin, 1972; Kester, 1975). Low organic-carbon contents associated with terrestrially dominated sediments (based on carbon-isotopic compositions) may be due to the small land area in the study area and its minimal runoff. Deposition in deep water, where marine organic matter is exposed to oxygenated water for long time periods, could also produce the low organic-carbon concentrations observed. Terrestrial organic matter may have been transported by downslope sediment movement.

Another terrestrial source indicator is the dominance of $n$-alkanes with an odd number of carbons in the $\mathrm{C}_{25}$ to $\mathrm{C}_{33}$ range (Farrington and Meyers, 1975; Farrington and Tripp, 1977; Gearing et al., 1976). Long chain, oddcarbon-number $n$-alkanes are produced from the degradation of terrestrial plant surface waxes used by the plants to prevent evaporation. These waxes are esters of long chain acids and alcohols. They appear to be the only in situ source of normal alkanes with chain lengths greater than about $n$ - $\mathrm{C}_{25}$ in recent sediments (Farrington and Meyers, 1975; Gearing et al., 1976; Tullock, 1976; Giger and Schaffner, 1977; Giger et al., 1980). At the sites investigated, no consistent $n$-alkane patterns were observed. This again may be due to low terrestrial input or to rapid biological reworking of the organic matter.

The random distribution of extractable organic matter is not simply related to organic matter content or type (Fig. 13). At the low levels encountered (generally $<500 \mathrm{ppm}$ ), the EOM must be controlled by biological input fluctuations that are not discernible with the methods used here or by biological reworking in the sediment column. Pristane/phytane ratios did not relate in any simple way to organic matter type, as might have been expected, because of the presumed phytoplankton origin of pristane (Fig. 14). As a ratio, this may reflect significant fluctuations in phytane distributions varying independently of pristane. The geochemistry of phytane (as well as pristane) is not well understood.

Perylene has been suggested as a terrestrial indicator, although attempts to relate perylene presence with known organic-matter source indicators have been unsuccessful. By using fluorescence intensity as a semiquantitative indicator of perylene the relationship observed was exactly opposite what would be expected if perylene was from a terrestrial source. High perylene fluorescence intensities were associated with what are considered typical marine organic-matter carbon isotopic compositions (Fig. 14). This could be due to the preservation of ma- 

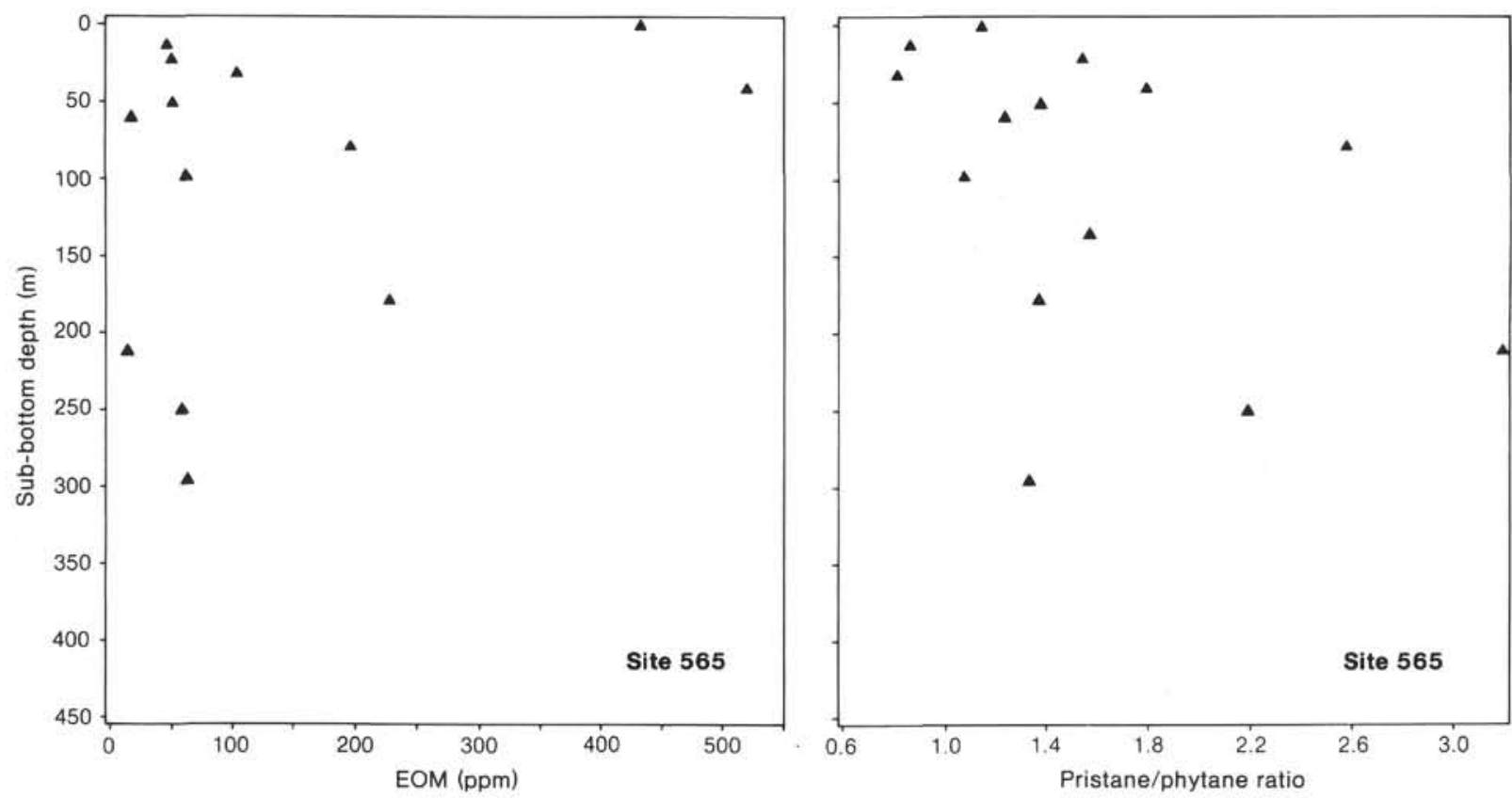

Figure 7. Distribution of hexane-extractable organic matter and pristane/phytane ratios with depth at Site 565.
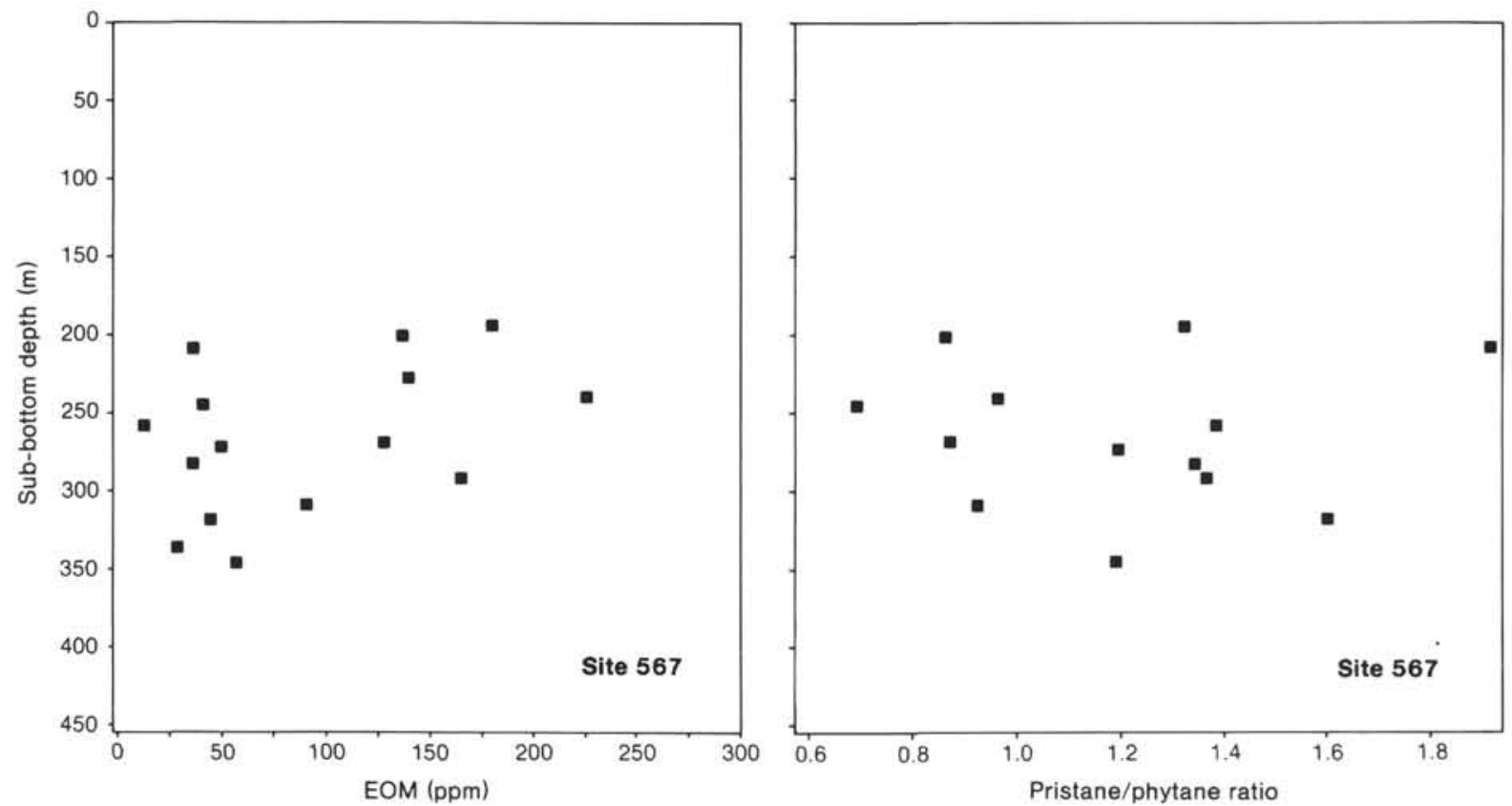

Figure 8. Distribution of hexane-extractable organic matter and pristane/phytane ratios with depth at Site 567.

rine-derived organic matter in environments of rapid deposition. Although perylene is rather labile in oxic marine sediments, it can be preserved under anaerobic conditions that are also favorable for the preservation of organic matter. The co-occurrence of perylene with marine-derived organic matter may be due to favorable oxygen conditions and not to source relationships.

In an effort to differentiate early diagenetic changes from organic facies (input) changes, the measured parameters were considered as a function of depth. Several complicating factors make the observed trends difficult to interpret: (1) sub-bottom depth does not correspond to a given geologic section, that is, very large differences in the thicknesses of specific geologic sections are observed from site to site; (2) slumping and mass movement causes mixing and sorting that introduce allocthonous material; (3) bioturbation tends to smear the geochemical signal; and (4) relative source inputs change from site to site. Other than the general decrease in organic-matter content and carbon isotopic ratios with depth, no diagenetic (or depth) related changes in the measured parameters were apparent (Figs. 15 and 16). 

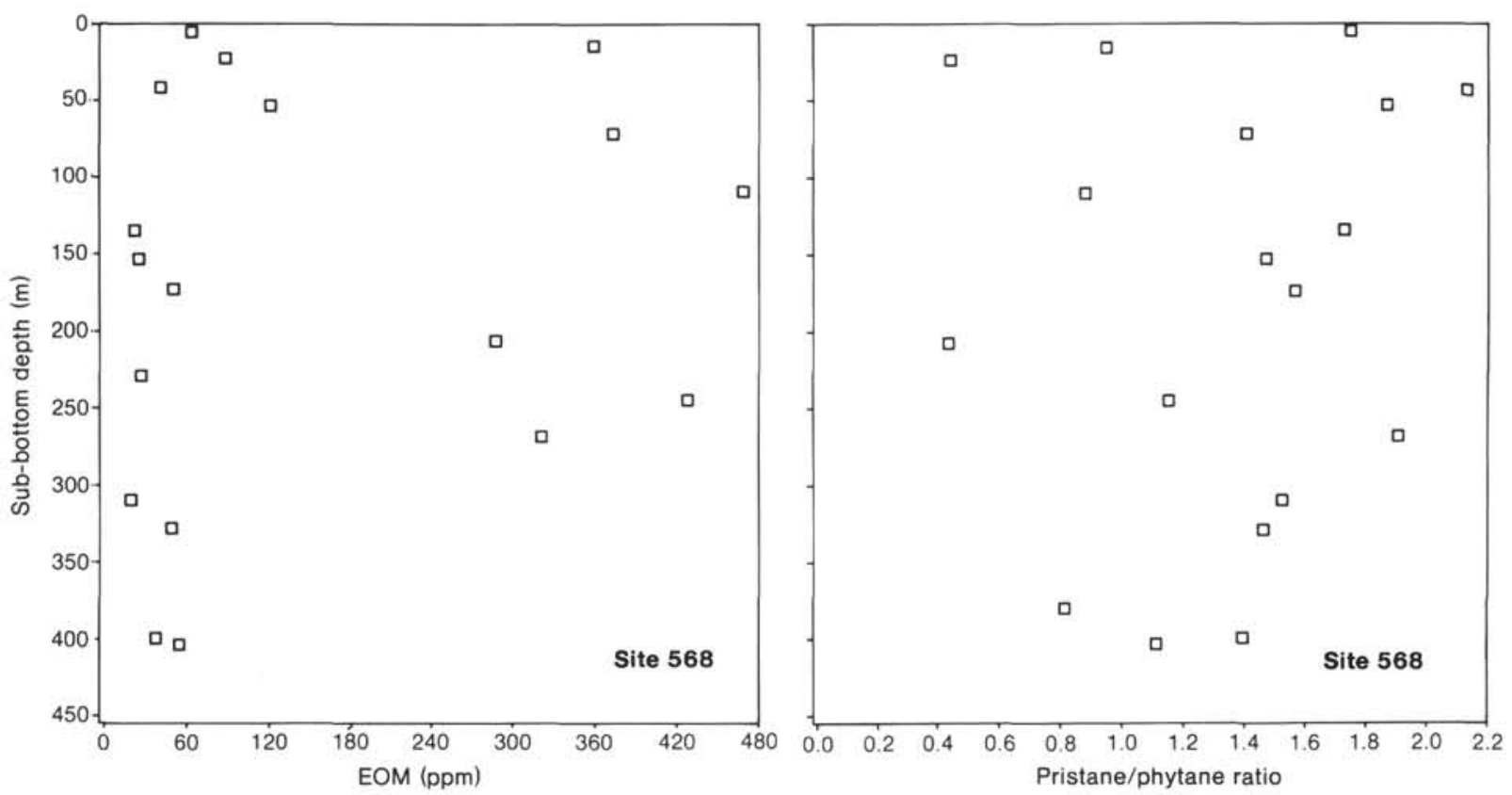

Figure 9. Distribution of hexane-extractable organic matter and pristane/phytane ratios with depth at Site 568.
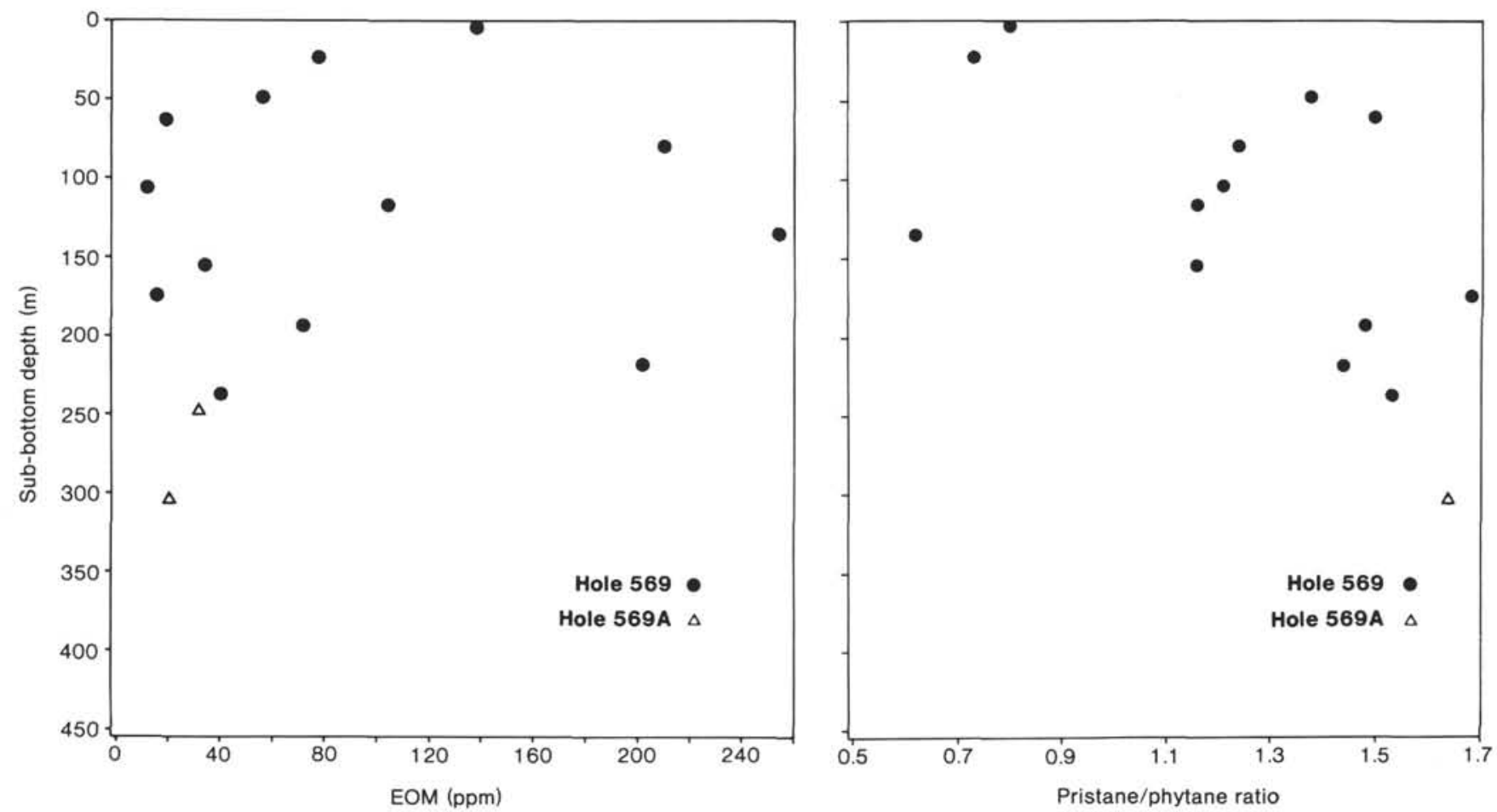

Figure 10. Distribution of hexane-extractable organic matter and pristane/phytane ratios with depth at Site 569.

This supports the conclusion that the molecular and isotopic distributions measured at these sites are related to changes in organic-matter source dynamics rather than to early diagenetic changes. Diagenetic changes are not significantly advanced to dilute original input and depositional environment fingerprints. This interpretation is consistent with the relatively low temperatures encountered at these sites.

\section{SUMMARY AND CONCLUSIONS}

Despite the long time scales represented by the samples analyzed at Site 565 through 570, average organiccarbon contents and carbon isotopic compositions were internally consistent within the Pleistocene and PlioceneOligocene sections (Table 1). The transect shows a decrease toward present-day land in organic-carbon con- 

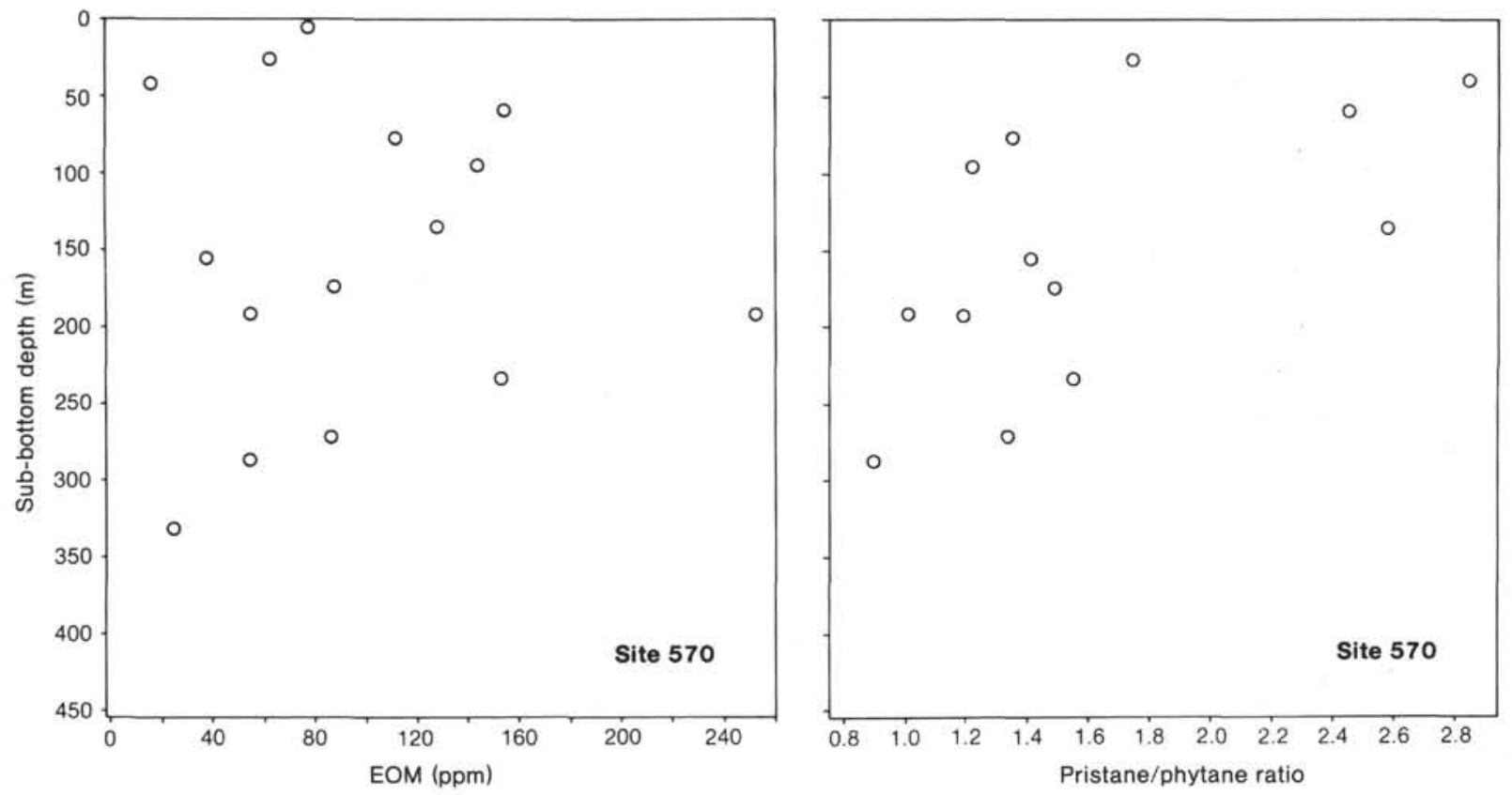

Figure 11. Distribution of hexane-extractable organic matter and pristane/phytane ratios with depth at Site 570 .

Table 1. Summary of the transect across the Middle America Trench, Leg 84 .

\begin{tabular}{|c|c|c|c|c|}
\hline \multirow[b]{2}{*}{ Age and Site ${ }^{a}$} & \multicolumn{2}{|c|}{$\begin{array}{c}\text { Organic-carbon } \\
\text { content }(\%)\end{array}$} & \multicolumn{2}{|r|}{$\begin{array}{c}\delta^{13} \mathrm{C}_{\text {org }} \\
\left(\%()_{0}\right)\end{array}$} \\
\hline & Average & Range & Average & Range \\
\hline \multicolumn{5}{|l|}{ Pleistocene } \\
\hline $\begin{array}{l}567 \text { (Cocos Plate) } \\
566 \text { (lower slope) } \\
569 \text { (middle slope! } \\
568 \text { (middle-upper slope) } \\
570 \text { (upper slope) }\end{array}$ & $\begin{array}{l}\text { N.S. } \\
3.97 \\
2.10 \\
2.20 \\
1.61\end{array}$ & $\begin{array}{c}\text { N.S. } \\
1.60-2.63 \\
0.52-4.18 \\
0.98-2.33\end{array}$ & $\begin{array}{l}\text { N.S. } \\
-20.8 \\
-20.4 \\
-21.0 \\
-20.8\end{array}$ & $\begin{array}{c}\text { N.S. } \\
-20.1 \text { to }-20.7 \\
-20.5 \text { to }-22.1 \\
-20.1 \text { to }-21.6\end{array}$ \\
\hline \multicolumn{5}{|l|}{ Pliocene-Oligocene } \\
\hline $\begin{array}{l}567 \text { (Cocos Plate) }^{d} \\
566 \text { (lower slope) } \\
569 \text { (middle slope) } \\
568 \text { (middle-upper slope) } \\
570 \text { (upper slope) }^{\mathrm{e}}\end{array}$ & $\begin{array}{l}0.62 \\
\text { N.S. } \\
0.69 \\
1.10 \\
1.96\end{array}$ & $\begin{array}{l}0.27-1.82 \\
\text { N.S. } \\
0.25-1.30 \\
0.52-1.79 \\
1.33-3.20\end{array}$ & $\begin{array}{l}-23.7 \\
\text { N.S. } \\
-23.3 \\
-23.3 \\
-21.3\end{array}$ & $\begin{array}{l}-21.3 \text { to }-26.1 \\
\text { N.S. } \\
-21.3 \text { to }-25.1 \\
-22.4 \text { to }-23.9 \\
-21.2 \text { to }-21.6\end{array}$ \\
\hline
\end{tabular}

Note: Site 565 is not in this transect (see Site 565 report, this volume).

a Sites listed from farthest offshore to closest nearshore with respect to present-day shoreline.

b No sample analyzed.

c Only one sample at Site 566.

Excludes serpentinite samples.

e Includes one lower Eocene sample.

tent and a very isotopically constant input during the Pleistocene. Because of the limited number of samples in the Pliocene-Oligocene sections, they will be considered as a group even though long time periods are represented by these sections. Carbon isotopic trends are internally consistent and relatively constant. There is a general increase in organic-carbon content proceeding toward present-day land. These sections generally have more negative $\delta^{13} \mathrm{C}$ values than the Pleistocene sections. A decrease in $\delta^{13} \mathrm{C}$ values also occurs in the direction of present-day land. This trend is accompanied by as much as a threefold increase in organic-matter content. From the data presented it is not possible to interpret the trends as resulting from organic-matter input, early diagenesis, or fluctuations in euphotic zone temperatures over geologic time. Other data from this laboratory suggest that early diagenesis and temperature fluctuations may be important in determining sedimentary organiccarbon isotopic composition.

\section{ACKNOWLEDGMENTS}

We thank the individuals of the Glomar Challenger for their help during the sampling procedures. We are also grateful to Alan Jeffrey, Debra Defreitas, and Der-Duen Sheu for their help in the analysis of organic-carbon and carbon isotopic compositions. Scott Schofield, Tamara Frank, Nancy Ardryszak, and Qui Zhu performed the extractions, gravimetry, and total scanning fluorescence. Research support for this study was provided by the Gas Research Institute Grant 5081363-0460 and National Science Foundation Grant OCE 8020560. We would also like to thank Dr. Pat Parker and Dr. Richard Scalan of the University of Texas, Port Aransas Marine Laboratory, for their helpful reviews.

\section{REFERENCES}

Brooks, J. M., Barnard, L. A., Wiesenburg, D. A., Kennicutt, M. C., and Kvenvolden, K. K., 1983. Molecular and isotopic compositions of hydrocarbons at Site 533, DSDP Leg 76. In Sheridan, R. E. Gradstein, F. M. et al., Init. Repts. DSDP, 76: Washington (U.S. Govt. Printing Office), 377-390.

Brooks, J. M., Kennicutt II, M. C., Barnard, L. A., Denoux, G. J., and Carey, B. D., 1983. Application of total scanning fluorescence to exploration geochemistry. Proc Offshore Technol. Conf., 4624: 393-400.

Calder, J. A., 1971. Carbon isotopic ratios of shelf sediments. [paper presented at 1971 Annual Meeting, Am. Geophysical Union, San Francisco, Ca.]

Craig, H., 1953. The geochemistry of the stable carbon isotopes. Geochim. Cosmochim. Acta, 3:53-92.

Eckleman, W. R., Broecker, W. S., Whitlock, D. W., and Allsup, J. R., 1962. Implications of carbon isotopic composition of total organic carbon of some recent sediments and ancient oils. Am. Assoc. Pet. Geol. Bull., 46:699-704.

Farrington, J. W., and Meyers, P. A., 1975. Hydrocarbons in the marine environment. In Eglinton, G. (Ed.), Environmental Chemistry (Vol. 1): London (The Chemical Society), 109-136. 
Farrington, J. W., and Tripp, B. W., 1977. Hydrocarbons in western north Atlantic sediments. Geochim. Cosmochim. Acta, 41: 1627-1641.

Gardner, W. S., and Menzel, D. W., 1974. Phenolic aldehydes as indicators of terrestrially derived organic matter in the sea. Geochim. Cosmochim. Acta, 38:813-822.

Gearing, P., Gearing, J. N., Lytle, T. F., and Lytle, J. S., 1976. Hydrocarbons in 60 northeast Gulf of Mexico sediments. A preliminary survey. Geochim. Cosmochim. Acta, 40:1005-1017.

Gearing, P., Plucker, F. E., and Parker, P. L., 1977. Organic carbon stable isotope ratios of continental margin sediments. Mar. Chem., 5:251-266.

Giger, W., and Schaffner, C., 1977. Aliphatic, olefinic and aromatic hydrocarbons in recent sediments of a highly eutrophic lake. In Campos, R., and Goni, J. (Eds.), Advances in Organic Geochemistry: Madrid (Endisma), pp. 375-390.

Giger, W., Schaffner, C., and Wakeham, S. G., 1980. Aliphatic and olefinic hydrocarbons in recent sediments of Greifensee, Switzerland. Geochim. Cosmochim. Acta, 44:119-129.

Harrison, W. E., Hesse, R., and Gieskes, J. M., 1981. Relationship between sedimentary facies and interstitial water chemistry of slope, trench, and Cocos Plate sites from the Middle American Trench transect, active margins off Guatemala, Deep Sea Drilling Project Leg 67. In Aubouin, J., von Huene, R., et al., Init. Repts. DSDP, 67: Washington (U.S. Govt. Printing Office), 603-613.

Hedges, J. I., 1975. Lignin compounds as indicators of terrestrial organic matter in marine sediments [Ph.D. thesis]. University of Texas at Austin.

Hedges, J. I., and Parker, P. L., 1976. Land-derived organic matter in surface sediments from the Gulf of Mexico. Geochim. Cosmochim. Acta, 40:1019-1029.

Hunt, J. M., 1970. The significance of carbon isotope variations in marine sediments. In Hobson, G. D., and Spears, G. C. (Eds.), Advances in Organic Geochemistry, 1966: Oxford (Pergamon), pp. 27-35.

Kennicutt II, M. C., and Brooks, J. M.,1983. Relationship between pelagic tar, fluorescence, and biological markers in the South Atlantic Ocean. Mar. Pollut. Bull., 14:335-342.

Kennicutt II, M. C., Brooks, J. M., and Denoux, G. J., in press. Carbon isotope, gas chromatography, and fluorescence techniques applied to the North Slope of Alaska correlation study. Am. Assoc. Pet. Geol. Bull.
Kester, D. R., 1975. Dissolved gases other than $\mathrm{CO}_{2}$. In Riley, J. P., and Skirrow, G. (Eds.), Chemical Oceanography: New York (Academic Press), pp. 498-556.

Lisitzin, A. P., 1972. Sedimentation in the world oceans. Soc. Econ. Paleontol. Mineral. Spec. Publ., 17:1-100.

Newman, J. W., Parker, P. L., and Behrens, E. W., 1973. Organic carbon isotope ratios in Quaternary cores from the Gulf of Mexico. Geochim. Cosmochim. Acta, 37:225-238.

Rovang, K., 1981. Relationship between sediment grain size and organic matter in a turbidite [M.S. thesis]. University of Tulsa.

Sackett, W. M., 1964. The depositional history and isotopic organic carbon composition of marine sediments. Mar. Geol., 2:173-185.

Sackett, W. M., Nakaparksin, S., and Dalrymple, D., 1970. Carbon isotope effects in methane production by thermal cracking. In Hobson, G. D., and Spears, G. C. (Eds.), Advances in Organic Geochemistry, 1966: New York (Pergamon), pp. 37-53.

Sackett, W. M., and Thompson, R. R., 1963. Isotopic organic carbon composition of recent continental derived clastic sediments of eastern Gulf coast, Gulf of Mexico. Am. Assoc. Pet. Geol. Bull., 47: 525-531.

Summerhayes, P. C., 1980. Organic facies of mid-Cretaceous black shales in the deep North Atlantic. SEPM Research Symposium: Hydrocarbon Source Bids, Their Depositional Environments and Early Diagenesis, Annual Meeting AAPG, Denver Bull. Am. Assoc. Pet. Geol., 64:750. (Abstract)

Summerhayes, C. P., and Gilbert, D., 1982a. Distribution, origin, and hydrocarbon potential of organic matter in sediments from the $\mathrm{Pa}$ cific Margin of Southern Mexico. In Watkins, J. S., and Moore, J. C., et al., Init. Repts. DSDP, 66: Washington (U.S. Govt. Printing Office), 547-546.

1982b. Distribution, origin, and hydrocarbon potential of organic matter in sediments from the Pacific margin of Guatemala. In Aubouin, J., von Huene, R., et al., Init. Repts. DSDP, 67: Washington (U.S. Govt. Printing Office), 595-599.

Tullock, A. P., 1976. Chemistry of waxes of higher plants. In Kilattukudy, P. E. (Ed.), Chemistry and Biochemistry of Natural Waxes: New York (Elsevier), pp. 236-287.

Wickman, F. E., 1952. Variations in the relative abundance of carbon isotopes in plants. Geochim. Cosmochim. Acta, 2:243-254.

Date of Initial Receipt: 23 January 1984

Date of Acceptance: 2 March 1984 

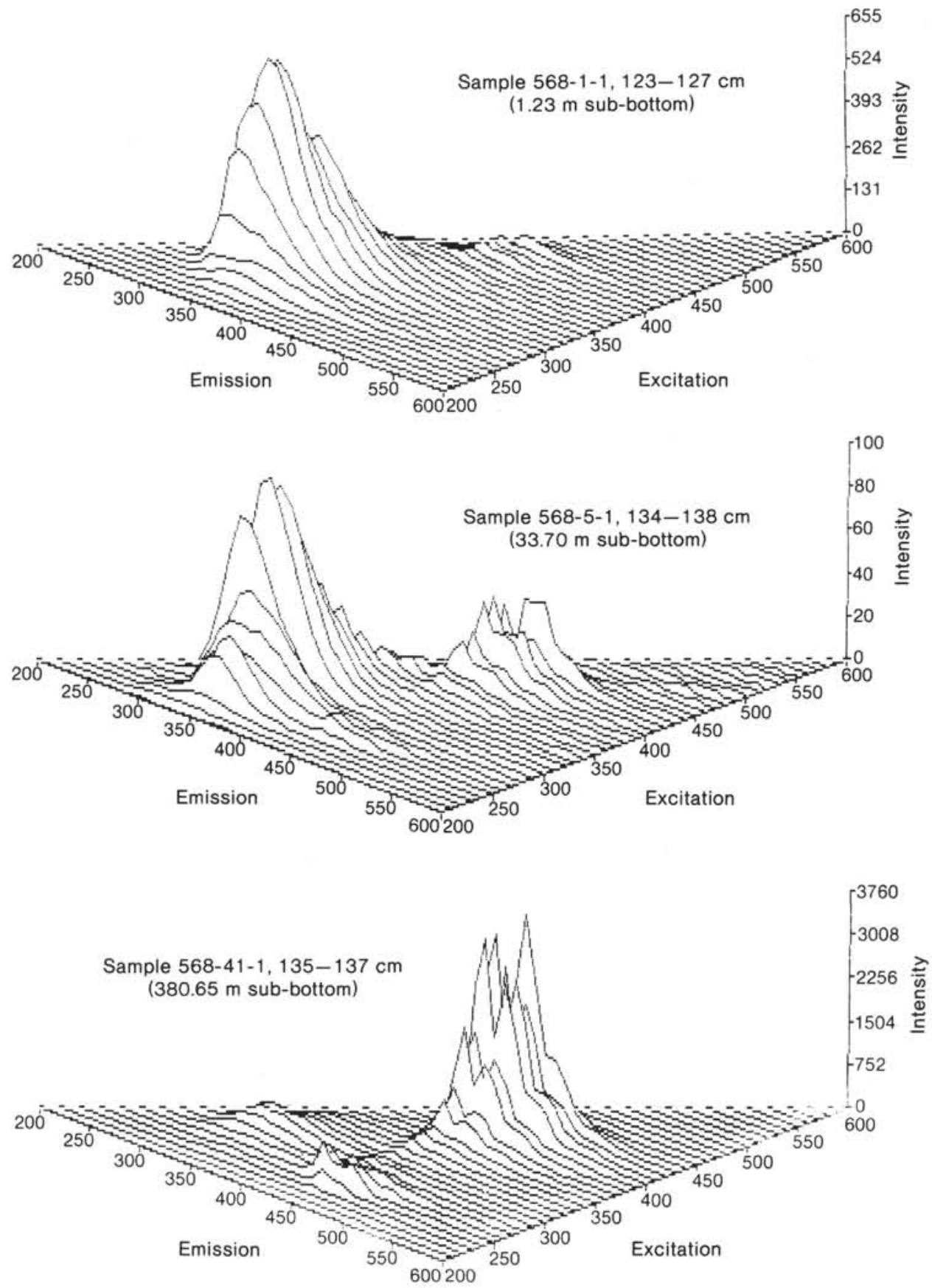

Figure 12. Representative total scanning fluorescence spectra from Site 568. 

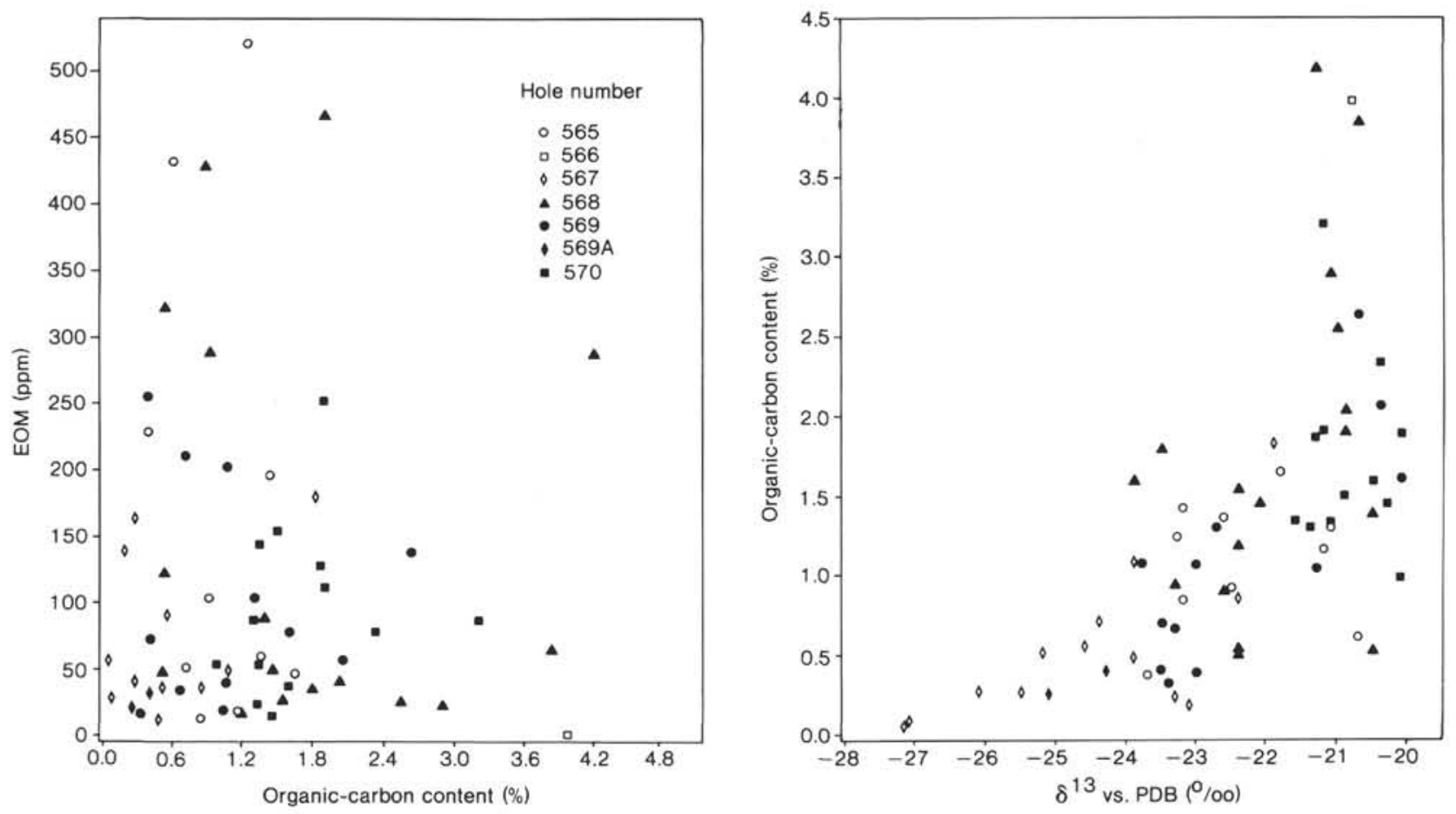

Figure 13. Plots of organic-carbon contents versus EOM and $\delta^{13} \mathrm{C}$ of organic carbon.
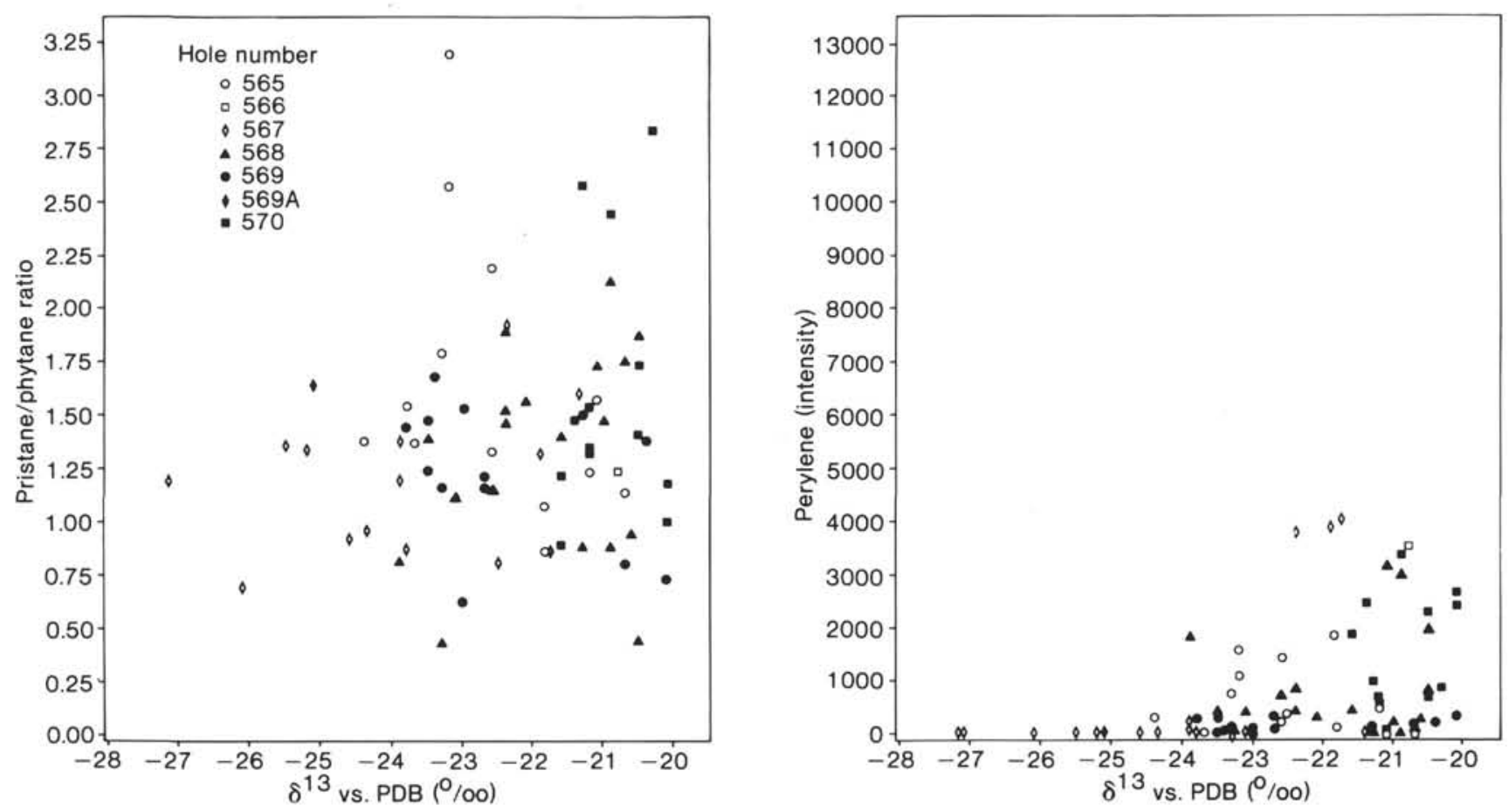

Figure 14. Plots of $\delta^{13} \mathrm{C}$ of organic carbon versus pristane/phytane ratios and perylene intensity. 

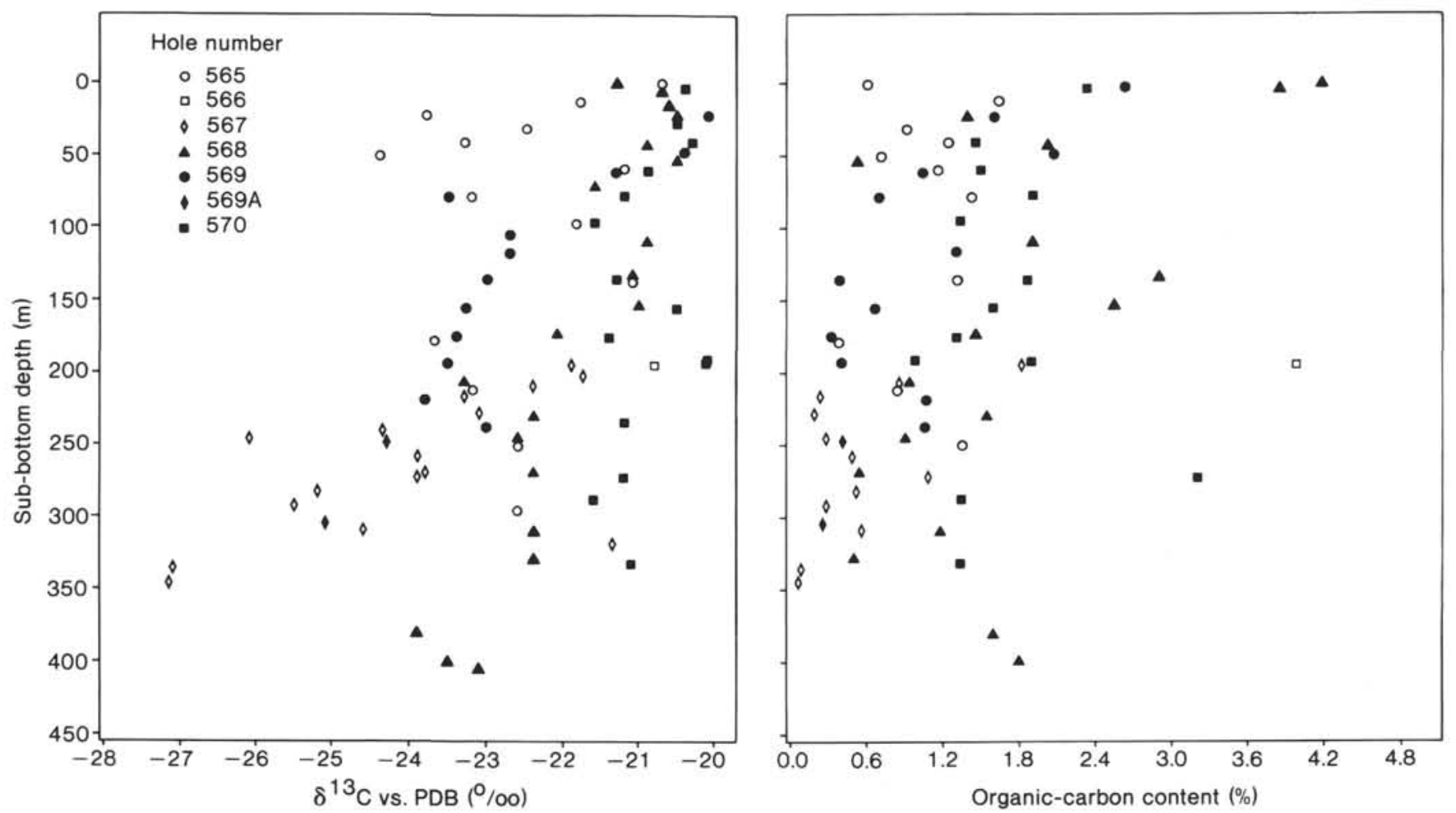

Figure 15. The variation in carbon isotopic composition and organic-carbon content with depth.
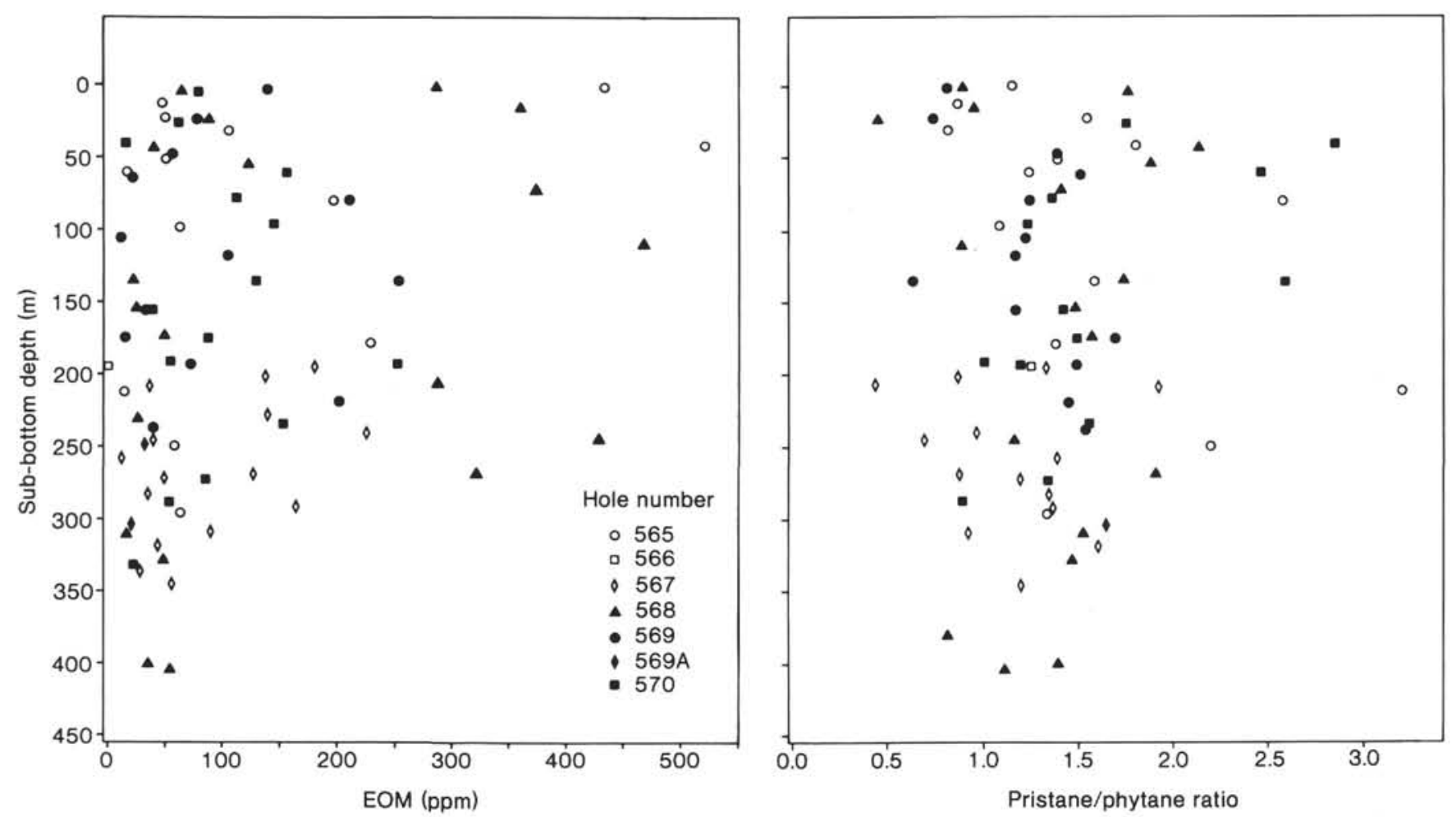

Figure 16. The variation in hexane-extractable organic matter and pristane/phytane ratios with depth. 